\title{
NEW FLAVONOIDS FROM THE AERIAL PARTS OF POLYGONUM EQUISETIFORME SM (POLYGONACEAE)
}

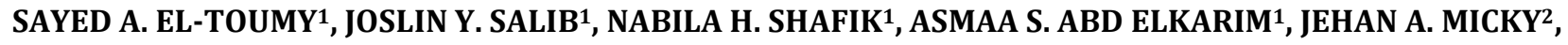 \\ AWATEF A. FARAG ${ }^{2}$
}

${ }^{1}$ Chemistry of Tannins Department, National Research Centre, El-Bohouth St., Dokki, 12622 Cairo, Egypt, ${ }^{2}$ Organic Chemistry Department, Faculty of Sciences, Al-Azhar University, Egypt

Email: sayedeltomy@yahoo.com

Received: 08 Oct 2016 Revised and Accepted: 21 Dec 2016

\section{ABSTRACT}

Objective: The current study was to deal the isolation and identification of secondary metabolites from Polygonum equisetiforme and evaluation of antioxidant activity of its extract.

Methods: The methanol-water extract (7:3) of the air-dried aerial parts of Polygonum equisetiforme was fractionated and separated to obtain the isolated compounds by different chromatographic techniques. Structures of these compounds were elucidated by UV apdaDDD/ C NMR spectroscopy and compared with the literature data. The crude extract was evaluated for in vitro antioxidant activity using the 2,2 diphenyl dipicryl hydrazine (DPPH) method.

Results: Ten secondary metabolites were isolated from Polygonum equisetiforme in this study. Of which three new flavonoids named as 3,5,7,2',5' pentahydroxyflavone 3-O- $\beta$-D-glucopyranoside (1), 3,5,7,2',5' pentahydroxyflavone 3-O- $\beta$-D-glucopyranoside 8 C-sulphated (2) and quercetin 3-O$\beta$-D-glucucorinde 6"-methyl ester 8-sulphated (3) as well as quercetin 3-O- $\beta$-D-glucucorinde methyl ester (4), quercetin 3-O- $\beta$-D-glucopyranoside (5), quercetin 7-O- $\beta$-D-glucopyranoside (6), quercetin (7), myricetin (8), $P$-methoxy gallic acid methyl ester (9) and gallic acid (10). The antioxidant potential of $P$. equisetiforme extract was evaluated by investigating it's total phenolic and flavonoid content and DPPH radical scavenging activity whereby the extract showed significant antioxidant activity ( $\mathrm{IC}_{50}=37.45 \mu \mathrm{g} / \mathrm{ml}$ ). The total phenolic and flavonoid content was found to be $130.79 \pm 5.502$ and $45.8 \pm 1.63 \mu \mathrm{g} / \mathrm{ml}$, respectively.

Conclusion: Polygonum equisetiforme is a promising medicinal plant, and our study tends to support the therapeutic value of this plant as an antioxidant drug.

Keywords: Polygonum equisetiforme, Aerial parts, New flavonoid, Antioxidant activity

(c) 2017 The Authors. Published by Innovare Academic Sciences Pvt Ltd. This is an open access article under the CC BY license (http://creativecommons.org/licenses/by/4. 0/) DOI: http://dx.doi.org/10.22159/ijpps.2017v9i2.15593

\section{INTRODUCTION}

Family Polygonaceae comprises about 40 genera and 800 species [1], distributed throughout the world, especially in temperate and warm regions. Polygonum is the largest genus belonging to the family Polygonaceae, which comprises about 300 species. According to Boulos [2] only six species are found in Egypt $P$. arena strum, $P$. avicular, $P$. bellardii, P. equisetiforme, P. marititimn and P. plebeium. The secondary metabolites identified in the species of the Polygonum genus are flavonoids [3-6], anthraquinones [7], lignan glycosides [8], polysaccharides [9], phenylpropanoid glycosides [10], sesquiterpene [11-13] and stilbenes $[14,15]$. Numerous polygonum species are frequently used in traditional medicine. Some species are used in the treatment of cough, diarrhea, diuretic agent and to treat urinary inflammation [16]. Turkish ethnomedicine reported the use of $P$. cognatum for the treatment of urinary inflammation and as diuretic agents [17]. The root extracts of $P$. multiflorum possess antiinflammatory [18], antioxidant [19], anti-HIV [20], and liver protective effects [21] as well as some monomeric compounds isolated from its roots. The medicinal properties of Polygonum species are due to its high constituents of bioactive compounds. Drimane sesquiterpenoids, norsesquiterpenoids and sulphatedlavonoids are characteristic compounds of some Polygonum species which reveal various biological activities, such as antifungal, antitumour and lens aldose reductase inhibitory [22-23]. Polysaccharide derivatives with radical scavenging and anti-tumour activities have been isolated from many Polygonum species [24, 25]. Flavonoids and chalcones isolated from some species of Polygonum on the other hand exhibit strong antioxidant effects role against oxidative stress damages, such as arteriosclerosis or cancer [26-29]. No comprehensive screening studies have yet been published on $P$. equisetiforme species. The current study was focused on the isolation and identification of flavonoids from the aqueous methanol extract of $P$. equisetiforme aerial parts, determination of the total phenolic and flavonoid contents together with studying the antioxidant activity of the extract.

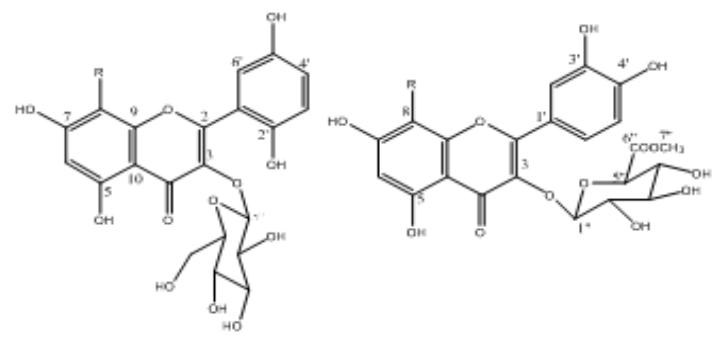

$1 \mathrm{R}=\mathrm{H} \quad 2 \mathrm{R}=\mathrm{SO}_{3} \mathrm{~K} \quad 3 \quad \mathrm{R}=\mathrm{SO}_{3} \mathrm{~K} \quad 4 \quad \mathrm{R}=\mathrm{H}$<smiles>Cc1cc(-c2oc3cc(O)cc(O)c3c(=O)c2O)cc(O)c1O</smiles>

$5 R_{t}=$ glucoside $R_{0}=R_{0}=H$

$7 \mathrm{R}_{\mathrm{t}}=\mathrm{R}_{\mathrm{s}}=\mathrm{R}_{3}=\mathrm{H}$

$6 \mathrm{R}_{\mathrm{s}}=$ glucoside $\mathrm{R}_{\mathrm{t}}=\mathrm{R}_{\mathrm{s}}=\mathrm{H}$<smiles>O=C(O)c1cc(O)c(O)c(O)c1</smiles>

$8 \mathrm{R}_{\mathrm{t}}=\mathrm{R}_{\mathrm{a}}=\mathrm{H} \quad \mathrm{R}_{\mathrm{g}}=\mathrm{OH}$

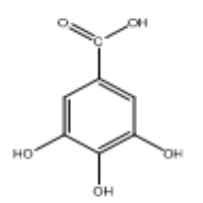

Fig. 1: Structures of the isolated compounds 


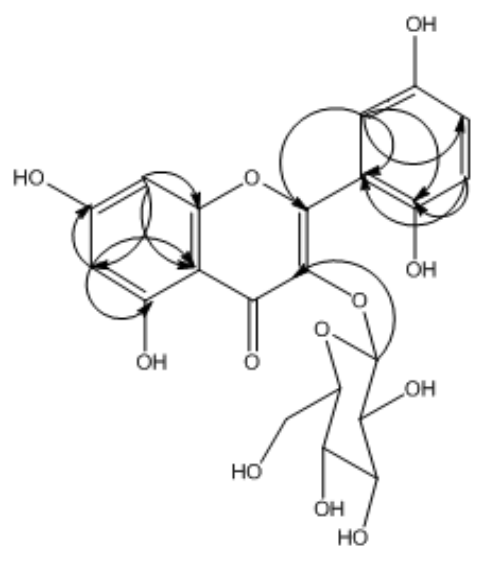

1

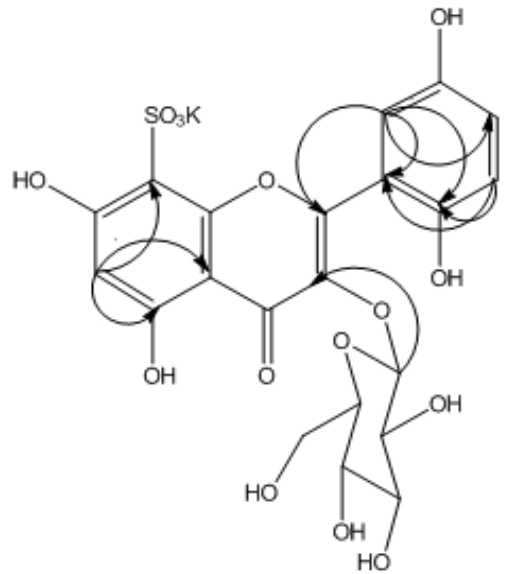

2

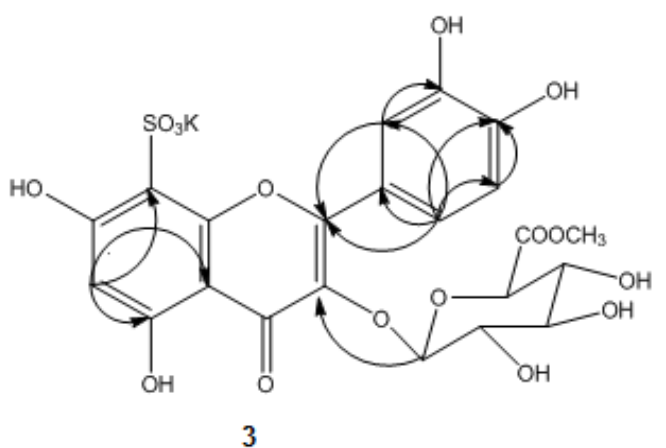

Fig. 2: $\mathrm{HMBC}$ correlations $\mathrm{H}-\mathrm{C}$ for 1, 2, 3

\section{MATERIALS AND METHODS}

\section{General experimental procedure}

${ }^{1} \mathrm{H}$ NMR and ${ }^{13} \mathrm{C}$ NMR spectra were obtained on Bruker AMX-400, Avance 400, and Avance 300 spectrometers (Bruker, Rheinstetten, Germany) with standard pulse sequences operating at $400,300 \mathrm{MHz}$ in ${ }^{1} \mathrm{H}$ NMR and 100, $75 \mathrm{MHz}$ in ${ }^{13} \mathrm{CNMR}$. Chemical shifts are given in $\delta$ values (ppm) using DMSO as the internal standard. UV spectra were recorded with Shimadzu UV-1601 (Shimadzu, Tokyo, Japan). Column chromatography (CC) was carried out on Polyamide 6S (Riedel-DeHaen, Hannover, Germany) and Sephadex LH-20 (Fluka, Pharmazia, Uppsala, Sweden); PC was carried out on Whatman No. 1 and $3 \mathrm{~mm}$ paper using the following solvent systems: (1) BAW (n$\mathrm{BuOH} / \mathrm{HOAc} / \mathrm{H}_{2} \mathrm{O}$, 4:1:5); (2) $\mathrm{H}_{2} \mathrm{O}$ and (3) $\mathrm{AcOH} / \mathrm{H}_{2} \mathrm{O}$ (15:85). 1, 1Diphenyl-2-picrylhydrazyl (DPPH), ascorbic acid, gallic acid, rutin and other chemicals were purchased from Sigma Chemical Co. (St. Louis, MO, USA). Folin-Ciocalteu solution and 95\% ethanol were purchased from Merck Co. (Santa Ana, CA, USA).

\section{Plant material}

A sample of $P$. equisetiforme (aerial parts) was collected from Mediterranean region, Egypt during April 2013 (flowering date). The samples were separately air-dried, powdered and kept in tightly-closed amber coloured glass containers and protected from light at low temperature. Identification of the plant was confirmed by Botany Department, Faculty of Science, Cairo University, Egypt [2]. A voucher specimen (P75) is deposited in the Herbarium of the National Research Centre, Dokki, Cairo, Egypt.

\section{Extraction and isolation}

The aerial parts of $P$. equisetiforme $(1.75 \mathrm{~kg})$ were crushed and extracted with $70 \%$ methanol by soaking at room temperature and the methanol extract was evaporated under reduced pressure and lyophilized $(120 \mathrm{gm})$. A sample $(100 \mathrm{gm})$ of the dry extract was fractionated by chromatography on polyamide $6 \mathrm{~S}$ column. The column was eluted with water and with water-methanol step gradient. The obtained fractions (500 $\mathrm{ml}$ of each fraction) were subjected to paper chromatography using BAW and 15\% acetic acid as a developing solvents, and the similar fractions were collected together to give six major fractions (I-VI). Separation of fractions II (200 mg) on Sephadex column LH-20 CC using 30\% EtOH gave two sub-fractions. The first sub-fraction was purified on Sephadex column $\mathrm{LH}-20 \mathrm{CC}$ using EtOH- $\mathrm{H}_{2} \mathrm{O}$ (1:1) as solvent system and gave a pure sample of 1 ( $25 \mathrm{mg}$ ), the second sub-fraction was subjected to Sephadex column LH-20 CC using EtOH-H $\mathrm{H}_{2} \mathrm{O}(30: 70)$ to give two compounds which were further purified on Sephadex CC using EtOH HPLC as solvent to give pure samples of $2(18 \mathrm{mg})$ and $3(30 \mathrm{mg})$. Fraction III (180 mg) have been applied on Sephadex column LH-20 CC using butanol-water saturated as solvent system and gave one compound which was further purified on Sephadex LH-20 CC using methanol HPLC to afford the purified sample of $4(25 \mathrm{mg})$. Elution of fraction IV (150 mg) by n-BuOH-water saturated; afforded two compounds which were separated by preparative paper chromatography using $150 \mathrm{AcOH}$ as eluent and were further purified on Sephadex LH-20 CC using EtOH- $\mathrm{H}_{2} \mathrm{O}$ (1:1) to give pure samples of $5(30 \mathrm{mg})$ and $6(28 \mathrm{mg})$. Consecutive CC on Sephadex LH-20 with n-butanol-water saturated for elution of fraction V (240 $\mathrm{mg}$ ) give two sub-fractions which were separated by preparative paper chromatography using BAW $(4: 1: 5)$ as eluent. These two compounds were further purified on Sephadex LH-20 CC using saturated n-butanol-water as eluent to afford pure samples of 7 (30 $\mathrm{mg}) 8(26 \mathrm{mg})$. Fraction VI (70 mg) has been separated on sephadex LH-20 CC using n-butanol-water saturated to give two compounds which were further purified on sephadex LH-20 CC using MeOH: $\mathrm{H}_{2} \mathrm{O}(1: 1)$ to give pure samples of 9 (30 mg) and $10(25 \mathrm{mg})$.

\section{$3,5,7,2^{\prime}, 5^{\prime}$ pentahydroxyflavone 3- $O$ - $\beta$-D-glucopyranoside (1)}

$\mathrm{R}_{\mathrm{f}}$ values (x100) 0.6 in (BAW), 0.8 in (HOAc-15\%); UV Spectral Data $\lambda_{\max }(\mathrm{nm}):$ MeOH: 253, 263sh, 344,+NaOMe: 284, 322sh, $372,+\mathrm{NaOAc}: \quad 272, \quad 330 \mathrm{sh}, \quad 390,+\mathrm{NaOAc} / \mathrm{H}_{3} \mathrm{BO}_{3}: \quad 260,290 \mathrm{sh}$, $375,+\mathrm{AlCl}_{3}: 260,415 \mathrm{sh}, 408,+\mathrm{AlCl}_{3} / \mathrm{HCl}: 266,401 \mathrm{~nm}$; ${ }^{1} \mathrm{HNMR}(400$ MHz, DMSO-d 6 ) $\delta$ (ppm): $8.28\left(1 \mathrm{H}\right.$, broad singlet, $\left.\mathrm{H}-6^{\prime}\right), 7.35(1 \mathrm{H}, \mathrm{dd}$, 
$J=8.4,1.9 \mathrm{~Hz}, \mathrm{H}-4$ '), $6.84\left(1 \mathrm{H}, d, J=8.4 \mathrm{~Hz}, \mathrm{H}-3^{\prime}\right), 6.40(1 \mathrm{H}, \mathrm{d}, J=1.5$ $\mathrm{Hz}, \mathrm{H}-8), 6.20(1 \mathrm{H}, \mathrm{d}, J=1.5 \mathrm{~Hz}, \mathrm{H}-6), 5.20(1 \mathrm{H}, d, J=6.8 \mathrm{~Hz}, \mathrm{H}-1 ")$, 3.24-3.82 (overlapped the rest sugar protons); ${ }^{13} \mathrm{C}$ NMR $(100 \mathrm{MHz}$, DMSO-d 6 ) $\delta$ (ppm): 156.50 (C-2), 134.07 (C-3), 177.59 (C-4), 160.94 (C-5), 98.96 (C-6), 164.77 (C-7), 93.78 (C-8), 157.60 (C-9), 103.64 (C10), 120.44 (C-1'), 148.45 (C-2'), 115.42 (C-3'), 120.66 (C-4'), 144.81(C-5'), 117.97 (C-6'), 103.03 (C-1"), 73.96 (C-2"), 74.15 (C3"), 71.76 (C-4"), 76.62 (C-5"), 63.06 (C-6").

\section{$3,5,7,2$ ', 5 ' pentahydroxyflavone 3 - $O$ - $\beta$-D-glucopyranoside 8-C- sulphated (2)}

$\mathrm{R}_{\mathrm{f}}$ values (x100) 0.5 in (BAW), 0.3 in (HOAc-15\%); UV Spectral Data $\lambda_{\max }(\mathrm{nm}): \mathrm{MeOH}: 258,270 \mathrm{sh}, 364,+\mathrm{NaOMe}: 225,278,410,+\mathrm{NaOAc}$ : $240,280,395,+\mathrm{NaOAc}^{-} \mathrm{H}_{3} \mathrm{BO}_{3}: 272,390,+\mathrm{AlCl}_{3}: 275,355 \mathrm{sh}$, $425,+\mathrm{AlCl}_{3} / \mathrm{HCl}$ : 278, 300sh, 330, $410 \mathrm{~nm}$; ${ }^{1} \mathrm{HNMR}$ (400 MHz, DMSO$\left.\mathrm{d}_{6}\right) \delta(\mathrm{ppm}): 8.37\left(1 \mathrm{H}\right.$, broad singlet, $\left.\mathrm{H}-6^{\prime}\right), 7.42(1 \mathrm{H}, \mathrm{dd}, J=8.4,1.9$ $\left.\mathrm{Hz}, \mathrm{H}-4^{\prime}\right), 6.83$ (1H, d, J = 8.4 Hz, H-3'), $5.93(1 \mathrm{H}, s, \mathrm{H}-6), 5.17$ (1H, d, J $=6.2 \mathrm{~Hz}, \mathrm{H}-1$ "), "), 3.21-3.56 (overlapped the rest sugar protons); [13]C NMR (100 MHz, DMSO-d 6 ) $\delta$ (ppm): 151.79 (C-2), 133.60 (C3), 175.62 (C-4), 155.3 (C-5), 97.68 (C-6), 185.58 (C-7), 98.82 (C-8), 154.60 (C-9), 103.45 (C-10), 120.38 (C-1'), 148.20 (C-2'), 115.40 (C3'), 120.88 (C-4'), 144.78 (C-5'), $117.50\left(\mathrm{C}^{6} \mathrm{6}^{\prime}\right), 100.98$ (C-1'), 72.55 (C-2"), 74.19 (C-3"), 69.85 (C-4"), 76.64 (C-5"), 63.11 (C-6").

\section{Quercetin 3-O- $\beta$-D-glucucorinde 6"-methyl ester 8-C-sulphated (3)}

$\mathrm{R}_{\mathrm{f}}$ values (x100): 0.44 in (BAW) and 0.41in (HOAc-15\%); UV Spectral Data $\lambda_{\max }(\mathrm{nm}):+\mathrm{MeOH} 258,364,+\mathrm{NaOMe}: 271,318(\mathrm{sh})$, $413,+\mathrm{NaOAc}: 270,377,+\mathrm{NaOAc} / \mathrm{H}_{3} \mathrm{BO}_{3}: 270,383 \mathrm{~nm} .{ }^{1} \mathrm{HNMR}(400$ $\left.\mathrm{MHz}, \mathrm{CD}_{3} \mathrm{OD}\right) \delta(\mathrm{ppm}): 7.74\left(1 \mathrm{H}, \mathrm{d}, J=2 \mathrm{~Hz}, \mathrm{H}-2^{\prime}\right), 7.72(1 \mathrm{H}, \mathrm{dd}, J=$ 8.6, $\left.1.8 \mathrm{~Hz}, \mathrm{H}-6^{\prime}\right), 6.86\left(1 \mathrm{H}, d, J=8.6 \mathrm{~Hz}, \mathrm{H}-5^{\prime}\right), 6.34(1 \mathrm{H}, \mathrm{s}, \mathrm{H}-6), 5.29$ $(1 \mathrm{H}, \mathrm{d}, J=7.6 \mathrm{~Hz}, \mathrm{H}-1 "), 3.64\left(3 \mathrm{H}, \mathrm{s}, \mathrm{OCH}_{3}\right), 3.29-3.78$ (overlapped the rest sugar protons). [13]C NMR (100 $\left.\mathrm{MHz}, \mathrm{CD}_{3} \mathrm{OD}\right) \delta(\mathrm{ppm})$ : 152.04 (C-2), 134.07 (C-3), 177.64 (C-4), 157.91 (C-5), 98.02 (C-6), 156.40 (C-7), 98.71 (C-8), 156.40 (C-9), 104.72 (C-10), 121.27 (C-1'), 114.57 (C-2'), 144.65 (C-3'), 148.87 (C-4'), 115.97 (C-5'), 122.39 (C$\left.6^{\prime}\right), 103.06\left(\mathrm{C}-1^{\prime \prime}\right), 73.89\left(\mathrm{C}-2^{\prime \prime}\right), 75.68\left(\mathrm{C}-3^{\prime \prime}\right), 71.34\left(\mathrm{C}-4^{\prime \prime}\right), 75.89$ (C$\left.5^{\prime \prime}\right), 169.27$ (C-6"), 51.47 (C-7").

\section{Total phenolic content}

The concentration of total phenolics of the plant extract and fractions was determined according to the method described by Kumar et al. [30]. Gallic acid was used as a standard. Briefly, a mixture of $100 \mu \mathrm{l}$ of plant extract (100 $\mu \mathrm{g}$ ml-1), $500 \mu \mathrm{l}$ of FolinCiocalteu reagent and $1.5 \mathrm{ml}$ of $\mathrm{Na}_{2} \mathrm{CO} 3(20 \%)$ was shaken and diluted up to $10 \mathrm{ml}$ with water. After $2 \mathrm{~h}$, the absorbance was measured at $765 \mathrm{~nm}$ using a spectrophotometer. All determinations were carried out in triplicate. The total phenolic concentration was expressed as gallic acid equivalents (GAE).

\section{Total flavonoid content}

Total flavonoid concentration of plant extract and fractions was determined according to the reported procedure by Kumaran and Karunakaran [31]. $100 \mu \mathrm{l}$ of plant extract (10 mg ml-1) in methanol was mixed with $100 \mu \mathrm{l}$ of $20 \% \mathrm{AlCl}_{3}$ in methanol and a drop of acetic acid and then diluted to $5 \mathrm{ml}$ with methanol. The absorbance was measured at $415 \mathrm{~nm}$ after $40 \mathrm{~min}$ against the blank. The blank consisted of all reagents and solvent without $\mathrm{AlCl}_{3}$. All determinations were carried out in triplicate. The total flavonoid concentration was expressed as rutin equivalents (RE).

\section{Determination of in vitro antioxidant activity}

The DPPH assay depends on measuring the scavenging ability of the antioxidant constituents of the extract using the stable DPPH radical [32]. Free radical scavenging activity was determined by radical scavenging assay. A solution of $0.1 \mathrm{mmol}$ DPPH in methanol was prepared. In a flat bottom 96 well-microplate, a total test volume of $200 \mu \mathrm{l}$ was used. In each well, $20 \mu \mathrm{l}$ of different concentrations (0$100 \mu \mathrm{g} / \mathrm{ml}$ final concentration) of tested samples were mixed with $180 \mu \mathrm{l}$ of methanolic DPPH and incubated for $30 \mathrm{~min}$ at $37^{\circ} \mathrm{C}$. Triplicate wells were prepared for each concentration, and the average was calculated. Then a photometric determination of absorbance at $520 \mathrm{~nm}$ was performed by microplate ELISA reader. Antioxidant activity $(\%)=[($ control absorbance-sample
absorbance $) /$ control absorbance $] \times 100 \%$

Antioxidant activity was expressed as the concentration of antioxidant that scavenged free radicals by $50 \%\left(\mathrm{IC}_{50}\right)$.

\section{RESULTS AND DISCUSSION}

The methanol-water extract (7:3) of the aerial parts of Polygonum equisetiforme was subjected to fractionation on a polyamide $6 \mathrm{~S}$ column gave three new compounds besides seven known compounds (1-10, fig. 1). The isolated compounds undergo conventional chemical and spectroscopic methods of analysis (UV, $1 / 2 \mathrm{D} \mathrm{NMR}$ ) as well as chromatography to elucidate their chemical structures.

Compound 1 was obtained as a yellow amorphous powder which showed chromatographic properties (dark purple spot on paper chromatogram under UV light). It gave lemon yellow color with Nature staff reagent [33] characteristic of flavonoids bearing a free hydroxyl at 5-position. UV spectral properties of 1, in methanol and after the addition of diagnostic reagents detected the presence of free 7-OH group [34]. ${ }^{1} \mathrm{H}$ NMR spectrum of 1 (DMSO- $d_{6}$, room temperature) displayed aromatic signals at $\delta$ ppm $\delta 8.28(\mathrm{~d}, J=1.9$ $\mathrm{Hz}), 7.35(\mathrm{dd}, J=8.4,1.9, \mathrm{~Hz})$ and $6.84(d, J=8.4 \mathrm{~Hz})$ describable to $\mathrm{H}-6^{\prime}, \mathrm{H}-4^{\prime}$ and $\mathrm{H}-3^{\prime}$ of $2^{\prime}, 5^{\prime}$-dihydroxy B-ring [35]. The AM-spin coupling system of two meta coupled protons doublets at $\delta 6.20$ and $6.40 \mathrm{ppm}$ with $J$-value $1.5 \mathrm{~Hz}$, assignable to $\mathrm{H}-6$ and $\mathrm{H}-8$, respectively concluded the 5, 7 dihydroxy A-ring. Also, ${ }^{1} \mathrm{H}$ NMR displayed one signal, a hexose anomeric proton resonance at $\delta 5.20(\mathrm{~d}, J=6.8 \mathrm{~Hz}$, $\left.\mathrm{H}-1^{\prime \prime}\right)$ specifying the presence of sugar with $\beta$-configuration. ${ }^{13} \mathrm{C}$ experiments showed methylene group, 10 methine and 10 quaternary carbons. The ${ }^{13} \mathrm{C}$ NMR spectrum of compound 1 showed one signal at $\delta 177.59$ assigned to the carbonyl carbon. Heteronuclear ${ }^{1} \mathrm{H}^{-13} \mathrm{C}$ correlation experiments (HMQC, HMBC) led to full assignments of the ${ }^{1} \mathrm{H}$ and ${ }^{13} \mathrm{C}$ NMR chemical shifts of compound 1. HSQC proton resonances are in good agreement with those of each corresponding carbon. However, the unequivocal assignment could be confirmed by HMQC and HMBC which proved that the signals at $156.50,164.77,160.94,157.60,148.45$ and 144.81 are assignable to C-2, C-7, C-5, C-9, C-2' and C-5' respectively. In the HMBC experiments, the correlation was observed between $\delta$ H 5.20 $\left(\mathrm{H}-1^{\prime \prime}\right)$ with $\delta \mathrm{C} 134.07$ (C-3) indicating that a glucosyl moiety is attached to $\mathrm{C}-3$. The HMBC correlation (fig. 2) was observed between $\delta_{\mathrm{H}} 8.28\left(\mathrm{H}-6^{\prime}\right)$ with $\delta_{\mathrm{c}} 120.44\left(\mathrm{C}-1^{\prime}\right)$ and $\delta_{\mathrm{c}} 156.50$ (C-2) indicated that the flavones with unusual B-ring. On the basis of these results, compound 1 was elucidated to be $3,5,7,2^{\prime}, 5^{\prime}$ pentahydroxyflavone 3- $O-\beta$-D-glucopyranoside. It is the first time for the isolation of this compound from any natural source.

Compound 2 was obtained as a yellowish powder which showed a dark purple spot on PC under UV light. UV spectral data showed the intrinsic chromatographic behaviour of flavonoid 3-O-glycoside with/without substitution in the A-ring. Compound 2 gave a positive sulphate test (a white ppt. with $\mathrm{BaCl}_{2}$ ) [36]. Investigation of the electrophoresis chromatogram showed the migration of 2 but with degradation, indicating the presence of a sensitive sulphate group. ${ }^{1} \mathrm{H}$ NMR data of 2 (DMSO- $d_{6}$, room temperature) displayed aromatic signals at $\delta$ ppm $\delta 8.37$ (broad singlet), $7.42(\mathrm{dd}, J=8.4,1.9 \mathrm{~Hz}$ ) and $6.83\left(\mathrm{~d}, J=8.4 \mathrm{~Hz}\right.$ ) describable to $\mathrm{H}-6^{\prime}, \mathrm{H}-4^{\prime}$ and $\mathrm{H}-3^{\prime}$ of $2^{\prime}, 5^{\prime}-$ dihydroxy B-ring. The A-ring has been concluded based on the spin coupling system of one singlet upfield proton at $\delta 5.93 \mathrm{ppm}$ assignable to $\mathrm{H}-6$ together with the absence of meta coupling suggested that the position 8 is substituted. Also, ${ }^{1} \mathrm{H}$ NMR displayed one signal, a hexose resonance at $\delta 5.17\left(\mathrm{~d}, J=6.2 \mathrm{~Hz}, \mathrm{H}-1^{\prime \prime}\right)$ indicating the presence of sugar with $\beta$-configuration. ${ }^{13} \mathrm{C}$ experiments showed methylene group, 10 methine and 10 quaternary carbons. The downfield signal at $(\delta 175.62)$ is assigned to the carbonyl carbon. The signals at $\delta 100.98$ (C-1"), 72.55 (C-2"), 74.19 (C-3"), 69.85 (C-4"), 76.64 (C-5"), and 61.11 (C-6") were achieved to the glucose moiety in compound 2 . The signals at $\delta$ 148.20 and 144.78 were assigned to $\mathrm{C}^{-2}$ ' and $\mathrm{C}-5^{\prime}$ positions, respectively, while the remaining ring $\mathrm{B}$ carbons appeared at $\delta$ 115.40 (C-3'), 117.50 (C-6'), 120.38 (C-1') and 120.88 (C-4'). In ${ }^{13} \mathrm{C}$ NMR spectrum the signal of $\mathrm{C}-8$ resonated at $\delta 98.82 \mathrm{ppm}$ with a downfield shift of 4 ppm while C-7 and C-9 resonated up field by 
about 4 ppm proving a sulphate substitution at C-8 [37]. Heteronuclear ${ }^{1} \mathrm{H}^{-13} \mathrm{C}$ correlation experiments (HMQC, HMBC) exhibited confirmation of the ${ }^{1} \mathrm{H}$ and ${ }^{13} \mathrm{C}$ NMR chemical shifts of compound 2. Also, the HSQC proton resonances are in good agreement with those of each corresponding carbon. In the HMBC spectrum (fig. 2) the proton signal at $\delta \mathrm{H} 5.17\left(\mathrm{H}-1^{\prime \prime}\right)$ displayed a long-range correlation with the carbon appeared at $\delta_{\mathrm{C}} 133.60(\mathrm{C}-3)$ suggesting a glucosyl moiety is attached to $\mathrm{C}-3$. The proton signal at $\delta_{\mathrm{H}} 8.37$ (H-6') showed long-range correlation with $\delta_{\mathrm{C}} 120.38\left(\mathrm{C}-1^{\prime}\right)$ and $\delta_{c} 151.79(\mathrm{C}-2)$ indicated that the flavones with unusual B-ring. On the basis of these results, compound 2 was elucidated to be $3,5,7,2^{\prime}, 5^{\prime}$ pentahydroxyflavone $3-O$ - $\beta$-D-glucopyranoside $8 \mathrm{C}$ sulphated. It is the first time for the isolation of this compound from any natural source.

Compound 3 was isolated as yellow amorphous powder and showed dark purple fluorescent spot turned to yellow and orange fluorescence on PC with ammonia vapours and Naturstoff spray reagents respectively [33]. The UV spectral of compound 3 in $\mathrm{MeOH}$ were similar to those of 3 -substituted quercetin except for a slight bathochromic shift of Band II (259 nm), supposed to be 8substituted and/or 6-substituted flavone [38]. The bathochromic shift $(\approx+60 \mathrm{~nm})$ accompanied with the increase in the intensity of band I on the addition of NaOMe indicated a free $\mathrm{OH}$ on $\mathrm{C}-4$ '. Also, the bathochromic shift in band II $(+20 \mathrm{~nm})$ was observed on the addition of $\mathrm{NaOAc}$ indicative to a free $\mathrm{OH}$ on $\mathrm{C}-7$. The presence of 3',4'-ortho-dihydroxy function on B-ring was also proved from the bathochromic shifts in the band I $(\approx+12 \mathrm{~nm})$ on the addition of $\mathrm{NaOAc}$ and $(\approx+17 \mathrm{~nm})$ in band II on the addition of $\mathrm{H}_{3} \mathrm{BO}_{3}$ [38]. Compound 3 gave a positive sulphate test (a white ppt. with $\mathrm{BaCl}_{2}$ ) [36]. Investigation of the electrophoresis chromatogram showed the migration of 3 but with degradation, indicating the presence of a sensitive sulphate group. The ${ }^{1} \mathrm{H}$ NMR spectrum of $3\left(\mathrm{CD}_{3} \mathrm{OD}\right.$, room temperature) showed aromatic signals at $\delta \mathrm{ppm} \delta 7.74(\mathrm{~d}, J=2 \mathrm{~Hz})$, $7.72\left(\mathrm{dd}, J=8.6,1.8 \mathrm{~Hz}\right.$ ), and $6.86\left(\mathrm{~d}, J=8.6 \mathrm{~Hz}\right.$ ) describable to $\mathrm{H}-2^{\prime}$, H-6' and H-5' of 3', 4'-dihydroxy B-ring of flavonoids [39]. Moreover, the H-6 proton appeared as a singlet $(\delta 6.34)$ and absent of meta coupling, suggesting the presence of the 8 - $C$-substituted. ${ }^{13} \mathrm{C}$ NMR spectrum showed twenty-two signals seven in the aliphatic region for the sugar moiety and methyl ester group and the remaining for the quercetin unit. The DEPT spectrum of compound 3 revealed for the presence of one methyl group at $\delta 51.47$ and four methine aromatic carbons. The presence of $\beta$-configuration of glucronic acid methyl ester in compound 3 was confirmed by the anomeric carbon resonance at $\delta 103.06$ and up the field of C-6" at $\delta$ 169.27. The downfield signals at ( $\delta 177.64$ and 169.27) were assigned to the two carbonyl carbons. The signals at $\delta 103.06$ (C-1"), 73.89 (C-2"), 75.68 (C-3"), 71.34 (C-4"), 75.89 (C-5"), and 169.22 (C-6") were achieved to the glucuronic moiety in the molecule. The presence of the $\mathrm{C}$ sulphated group substitution at position 8 in A-ring was confirmed from the downfield of C-8 at $\delta 98.71$ [37]. HMQC and HMBC spectral data are in good agreement with the ${ }^{1} \mathrm{H}$ and ${ }^{13} \mathrm{C}$ NMR chemical shifts of compound 3. HMBC correlation from H-1" at $\delta 5.29$ ppm to C-3 at $\delta 134.07$ suggested that the $\beta$-glucuronic acid methyl ester was connected to C-3 of the quercetin moiety. From the above data, compound 3 is deduced to be Quercetin 3-O- $\beta$-D-glucucorinde 6"methyl ester 8-sulphated. This compound was isolated for the first time from natural source.

The phenolic and flavonoid contents were 130.79 \pm 5.502 GAE/G extract and $45.8 \pm 1.63 \mathrm{mg} \mathrm{RE} / \mathrm{G}$ extract, respectively.

\section{The antioxidant activity assay}

The imbalance between oxidizing agents and the antioxidant defend system may lead to damage of the macromolecules [40] which consequently play a critical role in the pathogenesis of various diseases [41]. The plants have flavonoids and polyphenolic constituents that have remarkable antioxidant activity [42]. The hydromethanol extract of the aerial parts of $P$. equisetiforme exhibited a good anti-oxidant ability especially because of their phenolic compounds. It showed the significant scavenging activity of the free DPPH radical by $\mathrm{IC}_{50}=37.45 \mu \mathrm{g} / \mathrm{ml}$. The antioxidant potential of the plant proved the correlation between the phenolic and the flavonoid content and its antioxidant activity; indicating that these phenolic and flavonoid metabolites may be useful therapeutic agents.

\section{CONCLUSION}

The plants have flavonoid and polyphenolic constituents that have remarkable antioxidant activity. In this study, three new flavonoids neamed as $3,5,7,22^{\prime}, 5^{\prime}$ pentahydroxyflavone 3-O- $\beta$-Dglucopyranoside, $3,5,7,2$ ', 5' pentahydroxyflavone 3-O- $\beta$-Dglucopyranoside 8-C-sulphated and Quercetin 3-O- $\beta$-D-glucucorinde 6 "-methyl ester 8-C-sulphated isolated from the aqueous methanol of $P$. equisetiforme arial parts. The extract of the arial parts of $P$. equisetiforme exhibited a good anti-oxidant ability especially because of their phenolic compounds, including phenolic acids, flavonoids and their derivatives. Thus, further investigations are required in order to make optimal use of this plant.

\section{CONFLICT OF INTERESTS}

Declared none

\section{REFERENCES}

1. Mabberley DJ. Mabberley's plant-book: a portable dictionary of plants, their classification and uses, third edition. Cambridge University Press: UK; 2008.

2. Boulos L. In: Flora of Egypt. Vol. 1. Al Hadara Puplishing, Cairo, Egypt; 1999.

3. Datta BK, Datta SK, Rashid MA, Sarker SD. Flavonoids from Polygonum stagninum (Polygonaceae). Biochem Syst Ecol 2002;30:693-6.

4. Sun X, Sneden AT. Neoflavonoids from Polygonum perfoliatum. Plant Med 1999;65:671-3.

5. Hyoung JK, Eun RW, Hokoon P. A Novel lignan and flavonoids from Polygonum aviculare. J Nat Prod 1994;57:581-6.

6. Lopez SN, Sierra MG, Gattuso SJ, Furlan RL, Zacchino SA. An unusual homoisoflavanone and a structurally related dihydrochalcone from Polygonum ferrugineum (Polygonaceae). Phytochemistry 2006;67:2152-8.

7. Han L, Wu B, Pan G, Wang Y, Song X, Gao X. UPLC-PDA analysis for simultaneous quantification of four active compounds in crude and processed rhizome of Polygonum multiflorum Thunb. Chromatographia 2009;70:657-9.

8. Abd El-kader AM, Ahmed AS, Nafady AM, Ibraheim ZZ. Xanthone and lignan glycosides from the aerial parts of Polygonum bellardii all growing in Egypt. Pharmacogn Mag 2013;9:135-43.

9. Cui JJ, Yuan JF, Zhang ZQ. Anti-oxidation activity of the crude polysaccharides isolated from Polygonum cillinerve (Nakai) Ohwi in immunosuppressed mice. J Ethnopharmacol 2010;132:512-7.

10. Brown LL, Larson SR, Sneden AT. Vanicosides C-F, new phenylpropanoid glycosides from Polygonum pensylvanicum. J Nat Prod 1998;61:762-6.

11. Datta BK, Datta SK, Rashid MA, Nash RJ, Sarker SD. A sesquiterpene acid and flavonoids from Polygonum viscosum. Phytochemistry 2000;54:201-5.

12. Datta BK, Rashid MA, Datta SK, Sarker SD. Viscozulenic acid: a novel sesquiterpene acid from Polygonum viscosum. Pharm Biol 2001;39:198-201.

13. Haraguchi H, Matsuda R, Hashimoto K. High-performance liquid chromatographic determination of sesquiterpene dialdehydes and antifungal activity from Polygonum hydropiper. J Agric Food Chem 1993;41:5-7.

14. Kim HK, Choi YH, Choi JS, Choi SU, Kim YS, Lee KR, et al. A new stilbene glucoside gallate from the roots of Polygonum multiflorum. Arch Pharm Res 200;31:1225-9.

15. Chen LL, Huang XJ, Li MM, Ou GM, Zhao BX, Chen MF, et al. Polygonflavanol A, a novel flavonostilbene glycoside from the roots of Polygonum multiflorum. Phytochem Lett 2012;5:756-60.

16. Abdul Mazid M, Datta BK, Nahar L, Khairul Bashar SAM, Bachar SC, Sarker SD. Antinociceptive, anti-inflammatory and diuretic properties of Polygonum barbatum (L.) Hara var. barbata. Braz J Pharmacogn 2009;19:749-54. 
17. Cakilcioglu U, Turkoglu I. An ethnobotanical survey of medicinal plants in Sivrice (Elazı̆̆-Turkey). J Ethnopharmacol 2010;132:165-75.

18. Zhang YZ, Shen JF, Xu JY, Xiao JH, Wang JL. Inhibitory effects of $2,3,5,4^{\prime}$-tetrahydroxystilbene-2-O- $\beta$-D-glucoside experimental inflammation and cyclooxygenase 2 activity. J Asian Nat Prod Res 2007;9:355-63.

19. Chen Y, Wang MF, Rosen RT, Ho CT. 2,2-Diphenyl-1picrylhydrazyl radical scavenging active components from Polygonum multiflorum Thunb. J Agric Food Chem 1999;47: 2226-8.

20. Lin HW, Sun MX, Wang YH. Anti-HIV activities of the compounds isolated from Polygonum cuspidatum and Polygonum multiflorum. Planta Med 2010;70:889-92.

21. Wang MJ, Zhao RH, Wang WG, Mao XJ, Yu J. Lipid regulation effects of Polygoni multiflori radix, its processed products and its major substances on steatosis human liver cell line L02. J Ethnopharmacol 2012;139:287-93.

22. Fukuyama Y, Sato T, Asakawa Y, Takemoto T. A potent cytotoxic warburganal and related drimane-type sesquiterpenoids from Polygonum hydropiper. Phytochemistry 1982;21:2895-8.

23. Haraguchi H, Ohmi I, Sakai S, Fukuda A, Toihara Y, Fujimoto T, et al. Effect of Polygonum hydropiper sulfated flavonoids on lens aldose reductase and related enzymes. J Nat Prod 1996; 59:443-5.

24. Lv L, Cheng Y, Zheng T, Li X, Zhai R. Purification, antioxidant activity and antiglycation of polysaccharides from Polygonum multifforum Thunb. Carbohydr Polym 2014;99:765-73.

25. Lai XX, Li YP. Antitumor effect and mechanism of action of polysaccharides extracted from Polygonum perfoliatum L whole plant in human lung carcinoma A549 cell line. Trop J Pharm Res 2016;15:1243-9.

26. Yagi A, Uemura $\mathrm{T}$, Okamura $\mathrm{N}$, Haraguchi $\mathrm{H}$, Imoto $\mathrm{H}$, Hashimoto K. Antioxidative sulphated flavonoids in leaves of Polygonum hydropiper. Phytochemistry 1994;35:885-7.

27. Wang KJ, Zhang YJ, Yang CR. Antioxidant phenolic compounds from rhizomes of Polygonum paleaceum. J Ethnopharmacol 2005;96:483-7.

28. Peng Z, Strack D, Baumert A, Subramaniam R, Goh N, Chia T, et al. Antioxidant flavonoids from leaves of Polygonum hydropiper L. Phytochemistry 2003;62:219-28.

29. Wang, KW, Zhu JR, Shen LQ. A new lignan with anti-tumour activity from Polygonum perfoliatum L. Nat Prod Res 2013;27:568-73.
30. Kumar KS, Ganesan K, Rao PV. Antioxidant potential of solvent extracts of Kappaphycus alverezii (Doty) Doty-an edible seaweed. Food Chem 2008;107:289-5.

31. Kumaran A, Karunakaran J. In vitro antioxidant activities of methanol extracts of five Phyllanthus species from India. LWTFood Sci Technol 2007;40:344-52.

32. Ratty AK, Sunamoto J, Das NP. Interaction of flavonoids with 1,1-diphenyl-2-picrylhydrazyl free radical, liposomal membranes and soybean lipoxygenase-1. Biochem Pharmacol 1988;37:989-95.

33. Liu Y, Wu Y, Yuan K, Ji C, Hou AY, Yuan K, et al. Astragalin 2", 6"di-0-gallate from loropetalum chinense. Phytochemistry 1997;46:389-91.

34. Harborne JB, Williams CA. In: Harborne JB, Mabry TJ, Mabry H. Eds. The Flavonoids Chapman and Hall, London; 1975.

35. Wollenweber E, Marx D, Favre-Bonvin J, Voirin B, Kaouadji M. 3-metoxyflavones with unusual b-ring substitution from two species of Notholaena. Phytochemistry 1988;27:2673-6.

36. Yagi A, Uemura $\mathrm{T}$, Okamura $\mathrm{N}$, Haraguchi $\mathrm{H}$, Imoto $\mathrm{T}$, Hashimoto K. Antioxidative sulphated flavonoids in leaves of Polygonum hydropiper. Phytochemistry 1994;35:885-7.

37. Buchanan GW, Reyes-Zamora C, Clarke DE. A carbon-13 nuclear magnetic resonance investigation of some substituted methyl phenyl sulfide, sulfoxides, and sulfones. Can J Chem 1974;52:3895-904.

38. Mabry TJ, Markaham KR, Thomas MB. The systematic identification of flavonoids, Springer-verlag, Berlin; 1970.

39. Markham KR, Chari VM, Mabry TJ. The flavonoids: advances in research; Harbone JB, Mabry TJ. Eds. Chapman and Hall: London, UK; 1982.

40. Diaz MN, Frei B, Keaney JF, Vita JA. Antioxidants and atherosclerotic heart disease. N Engl J Med 1997;337:408-16.

41. Aruoma OI. Free radicals, oxidative stress and antioxidants in human and disease. J Am Oil Chem Soc 1998;75:199-212.

42. Brown JE, Rice-Evans CA. Luteolin-rich artichoke extract protects low-density lipoprotein from oxidation in vitro. Free Radical Res 1998;29:247-55.

\section{How to cite this article}

- $\quad$ Sayed A EL-Toumy, Joslin Y Salib, Nabila H Shafik, Asmaa S Abd Elkarim, Gihan A Mick. New flavonoids from the aerial parts of polygonum equisetiforme sm (Polygonaceae). Int J Pharm Pharm Sci 2017;9(2):166-170. 